九州大学学術情報リポジトリ

Kyushu University Institutional Repository

\title{
Life history parameters and temperature requirements for development of an aphid parasitoid aphelinus asychis (Hymenoptera: Aphelinidae)
}

Byeon, Young Woong

Institute of Biological Control, Graduate School of Bioresource and Bioenvironmental Sciences, Kyushu University I Crop Protection Division, National Academy of Agricultural Science (NAAS)

Tuda, Midori

Institute of Biological Control, Graduate School of Bioresource and Bioenvironmental Sciences, Kyushu University

\section{Takagi, Masami}

Institute of Biological Control, Graduate School of Bioresource and Bioenvironmental Sciences, Kyushu University

Kim, J.H.

Crop Protection Division, National Academy of Agricultural Science (NAAS)

他

http://hdl. handle. net/2324/27276

出版情報 : Environmental Entomology. 40 (2)，pp.431-440，2011-04. Entomological Society of America

バージョン :

権利関係: This article is the copyright property of the Entomological Society of America and may not be used for any commercial or other private purpose without specific written permission of the Entomological Society of America 
Life History Parameters and Temperature Requirements for Development of an Aphid Parasitoid Aphelinus asychis (Hymenoptera: Aphelinidae)

Y. W. Byeon ${ }^{1,2}$, M. Tuda ${ }^{1}$, M. Takagi ${ }^{1}$, J. H. Kim ${ }^{2}$, and M. Y. Choi ${ }^{2}$

${ }^{1}$ Institute of Biological Control, Graduate School of Bioresource and Bioenvironmental Sciences, Faculty of Agriculture, Kyushu University, Fukuoka, Japan

${ }^{2}$ Crop Protection Division, National Academy of Agricultural Science (NAAS), Suwon, South Korea

Corresponding author:

M. Tuda

tuda@grt.kyushu-u.ac.jp 
ABSTRACT We assessed the life history parameters and temperature requirement of a Korean population of the endoparasitoid Aphelinus asychis Walker (Hymenoptera: Aphelinidae), using Aphis gossypii Glover (Hemiptera: Aphididae) as a host. We first measured the time from egg to mummification (i.e., pupation) and mummification to adult emergence (i.e., pupal period) at $25^{\circ} \mathrm{C}$. The pupal period was significantly longer than the egg to pupation period in both genders, unlike in other regional populations of the species. Females produced an average of 342.9 mummies, the highest reported fecundity among the various regional populations of this species. Age-specific realized fecundity peaked between the 4-7th day (23.3-24.8 mummies a day). The intrinsic rate of increase $\left(r_{\mathrm{m}}\right)$ was 0.255 offspring per female per day.

The parasitoids were then reared at eight constant temperatures between 15 and $32.5^{\circ} \mathrm{C}$. The developmental time from egg to adult emergence decreased from 27.8 to $9.8 \mathrm{~d}$. The lower developmental thresholds $\left(T_{0}\right)$, estimated by linear regression, for the egg to mummy, mummy to adult, and egg to adult stages were $6.7,6.8$ and 6.7 , respectively. The thermal constants for each of the three periods were 115, 126, and 243 degree-days. We compared these parameters with published data of $A$. asychis from other regions reared on different hosts and representative species of aphid parasitoids in Aphidiinae (Braconidae) reared on hosts including A. gossypii. The $T_{0}$ 's of A. asychis were higher than those of Aphidius colemani and Aphidius matricariae when using A. gossypii.

\section{KEY WORDS}

cotton aphid, fecundity, temperature requirement, lower developmental threshold, thermal constant 
Temperature plays a major role in the ecology and population dynamics of insect pests and their natural enemies (Andrewartha and Birch 1954, Kontodimas et al. 2004). The relationship between temperature and developmental rates in insects is generally linear over the range of temperatures to which they are exposed. Conversely, development rate becomes nonlinear at extreme, sublethal temperatures (Wagner et al. 1984).

The lower developmental threshold is the temperature below which no development occurs, and the thermal constant is defined as the amount of heat required to complete development from egg to adult emergence of insects (Andrewartha and Birch 1954). These two parameters are important for the purposes of biological control as they aid in selection of natural enemies that are best adapted to environments favoring target pests and for predicting seasonal abundance on a physiological time-scale (Wagner et al. 1991, Jervis et al. 2005).

The cotton aphid, Aphis gossypii Glover (Hemiptera: Aphididae), is a polyphagous, cosmopolitan insect pest that has high reproductive potential (van Steenis and El-Khawass 1995 ) and infests cucurbitaceous crops including cucumber, watermelon and pumpkin as well as solanaceous crops including eggplant and tomato and malvaceous crops (cotton) (Kersting et al. 1999, Parrella et al. 1999). This aphid feeds on plant sap on underside of leaves and shoots, and can transmit viruses that result in reduced fruit yield (Hussein and Samad 1993). Aphid honeydew also promotes the growth of sooty mold fungus on the crop (Wood et al. 1988, Vasquez et al. 2006). Insecticides have been used extensively for control of A. gossypii but resistance to insecticides has been frequently observed (Kerns and Gaylor 1992, Wang et al. 2001). Given this, there have been a number of attempts to control A. gossypii using aphidiine parasitoids such as Aphidius colemani Viereck and Aphidius matricariae (Haliday) (Hymenoptera: Braconidae) (Bennison 1992, Bennison 
and Corless 1993, Goh et al. 2001, Nagasaka et al. 2005, Vasquez et al. 2006). However, control by these aphidiine parasitoids was not always successful in the greenhouses because of the impact of hyperparasitoids (Nagasaka et al. 2005), as well as the occurrence of non-preferred aphid hosts (i.e., Macrosiphum euphorbiae Thomas and Aulacorthum solani Kaltenbach (Hemiptera: Aphididae)) (Nagasaka et al. 2005, Tatsumi and Takada 2005, Van Driesche et al. 2008). Therefore, studies on additional biological control agents of the aphids are required, which could enhance success in control of aphids under various greenhouse conditions.

Aphelinus asychis Walker (Hymenoptera: Aphelinidae) is a polyphagous endoparasitoid that is native to Europe, Asia, and Africa. This species is capable of parasitizing and host-feeding on as many as 40 aphid species including A. gossypii (Bai and Mackauer 1990, Li et al. 2007). This parasitoid has been considered as a potential candidate for the biological control of four aphid species commonly found in greenhouses: A. gossypii, Myzus persicae Sulzer, A. solani and M. euphorbiae (Hemiptera: Aphididae) (Takada 2002).

Understanding the biological characteristics, such as development, reproduction and survival of a parasitoid species is essential for pre-evaluation of its effectiveness as a biological control agent. However, there have been few integrated studies on these parameters for A. asychis in East Asian countries. Thus, our objective was to characterize the developmental time of the immature stages, age-specific fecundity, and survival of $A$. asychis. We also compare these life history parameters with other regional strains of $A$. asychis and other Aphelinus species, some of which are closely related to A. asychis (Zhu and Fang 2009). Furthermore, the effect of temperature on the development of East Asian A. asychis population is not fully explored. Therefore, we investigated the temperature 
requirements (developmental threshold and thermal constant) and optimal temperature range (in terms of low pupal mortality and high proportions of females) of A. asychis. We compared these parameters with published data from other regional strains of the parasitoid and another taxonomic group of aphid parasitoid, Aphidiinae.

\section{Materials and methods}

\section{Insect Culture}

We obtained parasitoids (A. asychis) from the black mummies of Myzus persicae found on Chinese cabbage, Brassica campestris L., in Hoengseong, the northern part of South Korea and identified as A. asychis (Li et al. 2007). Stock cultures of this parasitoid were maintained on green bug, Schizaphis graminum (Rondani) (Hemiptera: Aphididae), cultured on barley, Hordeum vulgare L. var. chalbori because parasitoid rearing cost by using barley and S. graminum is lower than by using cucumber and A. gossypii. All insects were reared under a $16 \mathrm{~L}: 8 \mathrm{D}$ photoperiod in air-conditioned insectaries at $24-27^{\circ} \mathrm{C}$ and $50-70 \% \mathrm{RH}$.

\section{Development Times of Immature Stages}

We used cucumber (Cucumis sativus L. var. baekchimdadagi) seedlings at the three-tofive leaf stage and about $20 \mathrm{~cm}$ in height, cultured in planting media (Baroker, Seoul Bio Co., South Korea) in $8 \mathrm{~cm}$ diameter pots, in a growth chamber set at $25^{\circ} \mathrm{C}$ and $16 \mathrm{~L}: 8 \mathrm{D}$. Adults of A. gossypii were allowed to produce nymphs on the cucumber seedlings for $12 \mathrm{~h}$ and the nymphs were allowed to develop for 2-3 $\mathrm{d}$ to prepare the second and third instar $A$. gossypii in the air-conditioned insectaries. 
Mummies were placed in size 0 gelatin capsules (Bioquip, USA). After $24 \mathrm{~h}$, we determined the gender of the emergent parasitoid adults. One female and two male parasitoids were then placed in a plastic tube $(26 \times 67 \mathrm{~mm})$ for $4 \mathrm{~h}$ to facilitate mating. Following mating, 50 of the mated female wasps were placed into acrylic cages $(27 \times 27 \times$ $27 \mathrm{~cm}$ ) that contained cucumber seedlings infested with 150-350 second and third instar $A$. gossypii. The female wasps were allowed to oviposit for $8 \mathrm{~h}$. The parasitoids were then removed and the cucumber seedlings infested with A. gossypii were transferred to growth chambers and cultured at $25^{\circ} \mathrm{C}$ and $16 \mathrm{~L}: 8 \mathrm{D}$. We checked the aphids every $12 \mathrm{~h}$ for mummy formation, following the removal of the female parasitoids for parasitization. Each mummy was carefully collected using a fine hair brush and transferred individually to size 0 gelatin capsules. The capsules were held in the growth chamber until emergence of the parasitoids. We recorded the times of mummification (i.e., pupation) and adult emergence to derive the development time from egg (introduction of female parasitoids) to mummification, mummification to adult and egg to adult emergence (the sum of the former two measures).

\section{Age-specific Fecundity and Survival}

We estimated age-specific fecundity and survival of A. asychis using a cohort of $12 \mathrm{~A}$. asychis females that were reared from S. graminum. Parasitoid mummies were placed individually in size 0 gelatin capsules. We checked adult emergence every $12 \mathrm{~h}$ and determined the gender of each emerging individual. Each female was then caged with two males for $4 \mathrm{~h}$, after which one male was removed and the remaining male and the female were transferred together into an experimental arena containing $7 \mathrm{~cm}$ cucumber leaf disks infested with 50 2-2.5 day old nymphs, corresponding to the second instars, which were prepared as follows: Adults of A. gossypii were allowed to produce nymphs on cucumber 
seedlings for $12 \mathrm{~h}$. Then, 50 nymphs were inoculated on a cucumber leaf disk placed ventral-side-up on water-saturated cotton in a Petri dish $(9.3 \times 4 \mathrm{~cm})$ and allowed to develop for $2 \mathrm{~d}$. A round piece of gauze ( $4 \mathrm{~cm}$ diameter) was placed over a hole on the lid for ventilation. The Petri dishes were replaced every $24 \mathrm{~h}$ with a fresh dish containing a leaf disk with 50 A. gossypii until both the female and male parasitoids died. Each dish was held in an incubator at $25^{\circ} \mathrm{C}$ and $16 \mathrm{~L}: 8 \mathrm{D}$ until the aphids were mummified. The number of surviving adult parasitoids and the number of aphid mummies were recorded every $24 \mathrm{~h}$.

The values of net reproductive rate $\left(R_{0}\right)$, mean generation time $(T)$ and intrinsic rate of natural increase $\left(r_{\mathrm{m}}\right)$ were obtained with the following equation given by Birch (1948).

$$
\begin{gathered}
R_{0}=\sum l_{x} m_{x} \\
T=\sum x l_{x} m_{x} / R_{0} \\
\sum l_{x} m_{x} \exp \left(-r_{m} x\right)=1
\end{gathered}
$$

where $x$ is the female age (starting from 0 d-old egg), $l_{x}$ is the proportion of females surviving to the age, $m_{x}$ is the expected number of daughters produced per female alive at the age $x$, and $T$ is the generation time.

\section{Effect of Temperature on Development, Gender, and Pupal Mortality}

We prepared A. gossypii that were parasitized by A. asychis females on cucumbers in a growth chamber at $25^{\circ} \mathrm{C}$ and $16 \mathrm{~L}: 8 \mathrm{D}$ as described earlier. After oviposition, the parasitoids were removed and each plant was transferred into growth chambers adjusted to one of eight temperatures: $15,17.5,20,22.5,25,27.5,30$, or $32.5^{\circ} \mathrm{C}$, and $16 \mathrm{~L}: 8 \mathrm{D}$. The temperatures in the chambers were measured by HOBO Data Loggers (Onset Computer 
Corp., USA). Following the removal of the female parasitoids for parasitization, we observed the aphids twice each day (at $12 \mathrm{~h}$ intervals, starting from the time we introduced female parasitoids for oviposition) for mummy formation. Each mummy was carefully collected by using a fine hair brush and transferred individually to size 0 gelatin capsules. The capsules were held in the growth chambers at one of the eight temperatures and were checked twice a day for adult emergence. We recorded the gender of emerging parasitoid adults and the number of dead pupae. Pupae were considered dead if no parasitoid emerged from them for a week after emergence of parasitoids from the pupal population ceased. The possibility cannot be excluded that the $8 \mathrm{~h}$ parasitization period and subsequent transfer to cooler temperatures may have caused underestimation of development times at the lower temperatures.

\section{Statistical Analysis}

Developmental rate models. We investigated the effect of temperature on the developmental rate of three stages (i.e., egg to mummy, mummy to adult and egg to adult emergence) using linear regression. We used the model: $Y=b X+a$, where $Y$ is developmental rate (1/(number of days required for development)); $X$ is the temperature, $a$ and $b$ are the intercept and slope parameters obtained from the linear regression. The lower developmental threshold temperature $\left(T_{0}\right)$ is the intercept of the temperature axis of the regression (i.e., $T_{0}=-a / b$ ) and the thermal constant (degree-days, $D D$ ) is the reciprocal of the regression coefficient (i.e., thermal constant $=1 / b)($ Campbell et al. 1974). Data points that induced nonlinearity in development-temperature relation (i.e., $15^{\circ} \mathrm{C}$ and $32.5^{\circ} \mathrm{C}$ ) were discarded in the linear regression. SE's of $T_{0}$ and $D D$ were estimated following Campbell et al. (1974). 
Comparison with other aphid parasitoids. We analyzed the data for the egg-to-adult $T_{0}$ and $D D$ of $A$. asychis and aphidiine parasitoids (A. matricariae, A. colemani, and Diaeretiella rapae (McIntosh)) from published works. To ensure the thermal data were comparable to our study, we re-estimated the $T_{0}$ and $D D$ from the published studies by linear regression on mean temperatures, discarding data point(s) that would induce nonlinearity.

Life history parameters. We compared the development times for egg to mummification, mummification to adult emergence and egg to adult emergence between genders using unpaired $t$ tests. The time periods from egg to mummification and from mummification to adult emergence within each gender were also compared using unpaired $t$ tests. Relations between temperature and proportion of females or pupal mortality were analyzed using generalized linear models with logit link and binomial error family. Individuals died before reaching adult stage were discarded from the development time data.

Data on developmental times of the two genders were pooled for linear regression. We used Welch's test to analyze the effect of temperature on development of $A$. asychis because the test for homogeneity of variance for the development data deviated significantly among temperatures (Bartlett's test, $F=19.24 ; d f=7 ; P<0.0001$ for egg to mummy, $F=21.48 ; d f=7 ; P<0.0001$ for mummy to adult emergence, $F=8.58 ; d f=7 ; P$ $<0.0001$ for egg to adult emergence) after one-way ANOVA. We compared the lower temperature threshold and thermal constant between A. asychis and aphidiines using a nonparametric Wilcoxon-Mann-Whitney test (Wilcoxon 1945, Mann and Whitney 1947). 
JMP 8.0 (SAS Publishing 2008) was used to perform all the statistical tests.

\section{Results}

\section{Development Times of Immature Stages}

The development times from egg to mummy, mummy to adult emergence, and egg to adult emergence at $25^{\circ} \mathrm{C}$ were $6.0,7.9$ and $13.9 \mathrm{~d}$, respectively, for females and 5.9, 7.4 and $13.2 \mathrm{~d}$ for males (Table 1). The duration of development for the three immature periods were all significantly shorter in males than in females (for egg to mummification, $t=-3.47$, $d f=260, P<0.001$; for mummification to adult emergence; $t=-6.36, d f=260, P<$ 0.001; for egg to adult emergence, $t=-6.66, d f=260, P<0.001)$. The developmental time from mummification to adult emergence was significantly longer than that from egg to mummification in both genders (female: $t=31.5, d f=270, P<0.001$; male: $t=25.5, d f=$ $250, P<0.001)$

\section{Age-specific Fecundity and Survival}

When A. asychis encountered the host aphid A. gossypii, it touched A. gossypii with its antennae before inserting its ovipositor for host-feeding and ovipositing. Males and mated females survived 8.2 and 21.3 d, respectively at $25^{\circ} \mathrm{C}$ (Table 2, Fig. 1). On average, the female laid eggs that produced 14.9 mummies a day and a total of 342.6 mummies during her life span (Table 2). The fecundity of A. asychis was higher than in A. asychis from other locations (Appendix 1). 
Daily fecundity peaked (23.3-24.8 mummies a day) between the 4-7th day and increased and decreased repeatedly during the first 12 days, but declined gradually thereafter (Fig. 1). The daily fecundity curve is approximated by a typical triangular curve (Roff 1992, Kindlmann et al. 2001) in which mummy production first increased and then slowly decreased (Fig. 1).

Based on these data, the $r_{\mathrm{m}}$ of $A$. asychis at $25^{\circ} \mathrm{C}$ was $0.255 \mathrm{~d}^{-1}$. The $T$ and $R_{0}$ were 23.03 d and 145.1 female progenies, respectively.

\section{Effect of Temperature on Development, Gender, and Pupal Mortality}

The development times for each of the three immature periods of A. asychis were significantly different among the eight different rearing temperatures $\left(F_{7,472.9}=5397.7 ; P\right.$ $<0.0001$ for egg to mummy, $F_{7,471.9}=5925.4 ; P<0.0001$ for mummy to adult emergence, $F_{7,482.4}=7092.8 ; P<0.0001$ for egg to adult emergence) (Table 3$)$. The developmental time from egg to mummy decreased from 13.4 (at $15^{\circ} \mathrm{C}$ ) to $4.9 \mathrm{~d}\left(\right.$ at $32.5^{\circ} \mathrm{C}$ ) as temperature increased. Likewise, the development time from mummy to adult emergence decreased from 14.3 to $4.8 \mathrm{~d}$, and total time for immature development decreased from 27.8 to $9.8 \mathrm{~d}$, as temperature increased from 15 to $32.5^{\circ} \mathrm{C}$. The proportion of females and pupal mortality was not affected linearly by temperature (proportion of females, $\chi^{2}=0.0512, d f=1, P=$ 0.82; pupal mortality, $\left.\chi^{2}=0.0026, d f=1, P=0.96\right)$.

\section{Developmental Rate Models}

The rate of development of $A$. asychis from egg to mummy, mummy to adult emergence and egg to adult emergence increased linearly with temperature within the temperature range of $17.5-30^{\circ} \mathrm{C}$. The linear regression equations for developmental rate in 
relation to temperature for the three immature periods were estimated as in Table 3. Based on these equations, the lower developmental threshold temperatures and the thermal constants were estimated for the three developmental periods (Table 4).

\section{Comparison with Other Geographic Populations and Family}

The estimated lower developmental threshold $\left(T_{0}\right)$ of $A$. asychis was significantly higher than those of the two aphidiine species, A. colemani and A. matricariae when reared on A. gossypii (i.e., 1.96 SEs or 95\% confidence intervals did not overlap). The $T_{0}$ 's were also higher in seven geographical populations (or nine parasitoid-host population combinations $)$ of $A$. asychis than in aphidiine parasitoid species $\left(U_{6,9}=50.0, P<0.005\right.$, Appendix 2). We found no difference in the thermal constants (DD) between A. asychis and aphidiine parasitoids $\left(U_{6,9}=27.5, P>0.9\right.$, Appendix 2$)$.

\section{Discussion}

The pupal (i.e., mummy) period of both genders of the Korean population was longer than the egg to pupa period (Table 1). Furthermore, the pupal period of the Korean population ( $7.9 \mathrm{~d}$ in females and $7.4 \mathrm{~d}$ in males) was longer than that of the Kyoto population (6.6 d in females and $6.3 \mathrm{~d}$ in males, reared on $4-5 \mathrm{~d}$ old host), whereas the egg to mummy period was shorter in the former than the latter populations (Sengonca et al. 2008). These differences among the strains might be attributed partly to adaptation to local climates and/or attack by hyperparasitoids. Lee and Elliott (1998) demonstrated that $A$. asychis that is reared in a warmer climate has shorter developmental time in the pupal stage $\left(3.7 \mathrm{~d}\right.$ at $\left.26^{\circ} \mathrm{C}\right)$ than a strain reared in a cooler climate $\left(6.4 \mathrm{~d}\right.$ at $\left.26^{\circ} \mathrm{C}\right)$. The authors 
suggested that this is because the parasitoid is exposed to extreme high temperatures during the exposed, sessile pupal stage in the warmer climate. Desiccation may also be a critical factor for survival in this environment. In addition, pupal hyperparasitoids may play a role in shortening pupal period (Lee and Elliott 1998). Such evolution in the length of host vulnerable stage is observed in a laboratory host-parasitoid system (Pimentel et al. 1978). As a consequence of the shorter duration of vulnerability, host-parasitoid systems are more likely to persist (Tuda and Shimada 1995, 2005, Tuda 1996).

The fecundity of A. asychis in the present study was higher than in A. asychis from other locations with different host aphids (Appendix 1). The high level of fecundity that we observed might be a function of host availability. In our study there was an abundant supply of aphids that were suitable for both host-feeding and parasitization (see also Force and Messenger 1964a in Appendix 1). Furthermore, the number of mummies formed might vary across the distribution range of the parasitoids (Bernal and Gonzalez 1993). For example, Elliott et al. (1999) reported differences in mummy formation and survival rates in A. asychis from different regions (high in strains from Kazakhstan and China and low in a Moroccan strain). In addition, the body size of females, a proximate factor contributing to fecundity, is affected directly by the size (age) and suitability of hosts (see Sengonca et al. 2008 for A. asychis). Both the reared and experimental aphid species used in the present study are probably equally suitable as hosts, as was observed in the other East Asian population of A. asychis (Elliott et al. 1999) and might also explain, in part, the high fecundity we observed.

We speculate that the repeated increase and decrease in the daily fecundity is associated with host-feeding and subsequent oogenesis in a synovigenic parasitoid such as A. asychis (cf., Wu and Heimpel 2007). Daily fecundity increased most dramatically from 
6 to 21 during the first two days of the adult period. This corresponds with observations of the number of eggs in A. albipodus (Wu and Heimpel 2007), a potential sibling species of A. asychis (Zhu and Fang 2009).

We observed high fecundity and longevity of the South Korean A. asychis. These parasitoids also caused high mortality in A. gossypii by non-reproductive host killing (Byeon et al. 2009) as does the other East Asian population (Tatsumi and Takada 2005, Sengonca et al. 2008). A. asychis has high ability for host searching (in comparison with $A$. colemani, Byeon et al. 2011), a trait that is characteristic of aphelinid wasps in general (Viggiani 1984). Bernal and Gonzalez (1993) demonstrated that pupal mortality was lower in A. asychis (44 and $65 \%$ for different geographic strains at $29.4^{\circ} \mathrm{C}$ ) than in aphidiine wasps, A. matricariae (100\%) and D. rapae (92\%) at the same high temperature. They suggest that $A$. asychis is better adapted to regions of higher temperature than aphidiine parasitoid species. Pupal mortality of South Korean A. asychis range between 11.1-18.1\% at $27.5-32.5^{\circ} \mathrm{C}$ (Table 3 ) and this not only supports their suggestion but also indicate the Korean population is even more adapted to high temperature than are conspecific populations from Chile and France. Together, these observations suggest that the South Korean strain of $A$. asychis has considerable potential as a biological control agent of $A$. gossypii, supporting the consideration of aphelinids as important control agents of aphids in greenhouses (van Lenteren et al. 1997).

Temperature did not have a linear effect on the sex ratio of the offspring. However, optimal temperature for the production of the highest proportion of females was $22.5^{\circ} \mathrm{C}$ if the datum at $32.5^{\circ} \mathrm{C}$ was excluded (see later). Schlinger and Hall (1959) noted that the proportion of Aphelinus semiflavus (a junior synonym of A. aphelinus) females decreased as temperature increased (from $95-98 \%$ at $18.3-22.2^{\circ} \mathrm{C}$ to $\leq 1 \%$ at $25.6-29.4^{\circ} \mathrm{C}$ ). 
Conversely, the proportion of females was highest at intermediate temperatures (64-65\% at $18-27^{\circ} \mathrm{C}$ ) in Aphelinus gossypii (Tang and Yokomi 1995). Likewise, there was no linear relation between temperature and sex ratio in Aphelinus spiraecolae, and the proportion of females was highest at the two extreme temperatures, $15^{\circ} \mathrm{C}(70.8 \%)$ and $30^{\circ} \mathrm{C}(69.3 \%)$. In our study, proportion of females at $32.5^{\circ} \mathrm{C}$ was higher than other temperatures and the size of dead mummies was very small (Y. W. B., pers. observ.). Aphelinid wasps are known to allocate male progeny to small hosts, as do other hymenopteran insects. Given this, it is likely that the mortality is gender-biased towards males at the highest temperature.

The response of parasitoid to ambient temperature is one of many attributes, including fecundity, search efficiency, and host preference that, acting in concert with environmental factors, will determine the outcome of attempts at biological control of a host (Bernal and Gonzalez 1993). Besides climate, host aphids may also affect the thermal requirements of the parasitoid (Raney et al. 1971). Therefore, integration of available knowledge on environment and species combination to target will be required for each specific case of biological control.

Given that parasitoids have difficulty in colonizing an area when hosts have not reached a developmental stage suitable for parasitization, the success of biological control efforts might depend on the use of natural enemies that emerge after host development (Campbell et al. 1974). The onset of seasonal emergence of parasitoids might be estimated using the lower developmental threshold. Thus, parasitoids with a higher developmental threshold than their hosts are expected to appear later than their hosts (Bernal and Gonzalez 1993). The developmental threshold of $A$. asychis $\left(6.7^{\circ} \mathrm{C}\right)$ estimated in the present study was higher than that of its host, A. gossypii $\left(5.0^{\circ} \mathrm{C}, \mathrm{Kim}\right.$ et al. 2004). However, other ecological factors such as diapause (Tatsumi and Takada 2006), foraging 
behavior (Li et al. 1992, De Farias and Hopper 1999), searching efficiency, functional response (Bai and Mackauer 1990, Byeon et al. 2011), and host preference, as well as evolutionary potential of these traits (c.f., Tuda and Bonsall 1999, Hufbauer and Roderick 2005) must be considered prior to using this parasitoid in biological control program.

\section{Acknowledgments}

We are thankful to Dr. B. R. Choe of NAAS for collection of A. asychis, Dr. C-. D. Li of Northeast Forestry University, Harbin, China, for identification of this parasitoid and two anonymous reviewers for insightful comments. This research was performed as a part of Ph. D study of the first author and supported in part by a Grant-in-Aid for Scientific Research from JSPS to MT. 


\section{References Cited}

Andrewartha, H. C., and L. C. Birch. 1954. The distribution and abundance of animals. The University of Chicago Press, Chicago, IL.

Bai, B., and M. Mackauer. 1990. Oviposition and host-feeding patterns in Aphelinus asychis (Hymenoptera: Aphelinidae) at different aphid densities. Ecol. Entomol. 15: 9-16.

Bennison, J. A. 1992. Biological control of aphids on cucumber: Use of open rearing systems or "banker plants" to aid establishment of Aphidius matricariae and Aphidoletes aphidimyza. Med. Fac. Landbouww Univ. Gent. 57: 457-466.

Bennison, J. A., and S. P. Corless. 1993. Biological control of aphids on cucumber: Further development of open rearing units or "banker plant" to aid establishment of aphid natural enemies. Bull. IOBC/WPRS 6: 146-150.

Bernal, J., and D. Gonzalez. 1993. Temperature requirements of four parasites of the Russian wheat aphid Diuraphis noxia. Entomol. Exp. Appl. 69: 173-182.

Bernal, J., M. Waggoner, and D. Gonzalez. 1997. Reproduction of Aphelinus albipodus (Hymenoptera: Aphelinidae) on Russian wheat aphid (Hemiptera: Aphididae) hosts. Eur. J. Entomol. 94: 83-96.

Birch, L. C. 1948. The intrinsic rate of natural increase of an insect population. J. Anim. Ecol. 17: $15-26$.

Byeon, Y. W., M. Tuda, J. H. Kim, and M. Y. Choi. 2011. Functional responses of aphid parasitoids, Aphidius colemani (Hymenoptera: Braconidae) and Aphelinus asychis (Hymenoptera: Aphelinidae). Biocontrol Sci. Tech. 21: 57-70.

Byeon, Y. W., M. Tuda, M. Takagi, J. H. Kim, and Y. H. Kim. 2009. Non-reproductive host killing caused by Aphelinus asychis (Hymenoptera: Aphelinidae), a parasitoid of cotton aphid, Aphis gossypii (Homoptera: Aphididae). J. Fac. Agric. Kyushu Univ. 54: 369-372. 
Campbell, A., B. D. Frazer, N. Gilbert, A. P. Gutierrez, and A. P. Mackauer. 1974. Temperature requirements of some aphids and their parasites. J. Appl. Ecol. 11: 431-438.

Cate, R. H., T. L. Archer, R. D. Eikenbary, K. J. Starks, and R. D. Morrison. 1973. Parasitization of the greenbug by Aphelinus asychis and the effect of feeding by the parasitoid on aphid mortality. Environ. Entomol. 2: 549-553.

De Farias, A. M. I., and K. R. Hopper. 1999. Oviposition behavior of Aphelinus asychis (Hymenoptera: Aphelinidae) and Aphidius matricariae (Hymenoptera: Aphidiidae) and defense behavior of their host Diuraphis noxia (Homoptera: Aphididae). Environ. Entomol. 28: 858862.

Elliott, N. C., J. H. Lee, and S. D. Kindler. 1999. Parasitism of several aphid species by Aphelinus asychis (Walker) and Aphelinus albipodus Hayat and Fatima. Southwest. Entomol. 24: 5-12.

Force, D. C., and P. S. Messenger. 1964a. Fecundity, reproductive rates, and innate capacity for increase of three parasites of Therioaphis maculata (Buckton). Ecology 45: 706-715.

Force, D. C., and P. S. Messenger. 1964b. Duration of development, generation time, and longevity of three hymenopterous parasites of Therioaphis maculata, reared at various constant temperatures. Ann. Entomol. Soc. Am. 57: 405-413.

Goh, H. G., J. H. Kim, and M. W. Han. 2001. Application of Aphidius colemani Viereck for control of aphid in greenhouse. J. Asia-Pacific Entomol. 4: 171-174.

Hamilton, P. A. 1973. The biology of Aphelinus flavus (Hymenoptera: Aphelinidae), a parasite of the sycamore aphid Drepanosiphum platanoidis (Hemiptera: Aphididae). Entomophaga 18: $449-462$.

Höller, C., and H. Haardt. 1993. Low field performance of an aphid parasitoid, Aphelinus abdominalis, efficient in the laboratory (Hym., Aphelinidae). Entomophaga 38: 115-124. 
Hufbauer, R. A., and G. K. Roderick. 2005. Microevolution in biological control: Mechanisms, patterns, and process. Biol. Control 35: 227-239.

Hussein, M. Y., and N. A. Samad. 1993. Intercropping chilli with maize or brinjal to suppress populations of Aphis gossypii Glov. and transmission of viruses. Int. J. Pest Manag. 39: 216222.

Jervis, M. A., M. J. W. Copland, and J. A. Harvey. 2005. The life cycle, pp. 73-165. In M. A. Jervis (ed.), Insects as natural enemies - a practical perspective, Springer, Berlin.

Kerns, D. L., and M. J. Gaylor. 1992. Insecticide resistance in field populations of the cotton aphid (Homoptera: Aphididae). J. Econ. Entomol. 85: 1-8.

Kersting, U., S. Satar, and N. Uygun. 1999. Effect of temperature on development rate and fecundity of apterous Aphis gossypii Glover (Homoptera: Aphididae) reared on Gossypium hirsutum L. J. Appl. Entomol. 123: 3-27.

Kim, J-.S., Y-. H. Kim, T-. H. Kim, J-. H. Kim, Y-. W. Byeon, and K-. H. Kim. 2004. Temperature-dependent development and its model of the melon aphid, Aphis gossypii Glover (Homoptera: Aphididae). Kor. J. Appl. Entomol. 43: 111-116 (in Korean with an English abstract).

Kindlmann, P., A. F. G. Dixon, and I. Dostalkova. 2001. Role of ageing and temperature in shaping reaction norms and fecundity functions in insects. J. Evol. Biol. 14: 835-840.

Kontodimas, D. C., P. A. Eliopoulos, G. J. Stathas, and L. P. Economou. 2004. Comparative temperature-dependent development of Nephus includens (Kirsch) and Nephus isignatus (Boheman) (Coleoptera: Coccinellidae) preying on Planococcus citri (Risso) (Homoptera: Pseudococcidae): evaluation of linear and various nonlinear models using specific criteria. Environ. Entomol. 33: 1-11.

Lee, J. H., and N. C. Elliott. 1998. Comparison of developmental responses to temperature in 
Aphelinus asychis (Walker) from two different geographic regions. Southwest. Entomol. 23: $77-82$.

Li, C., B. D. Roitberg, and M. Mackauer. 1992. Comparison of developmental responses to temperature in Aphelinus asychis, for its host. Oikos 65:207-212.

Li, C-. D., Y. W. Byeon, and B. R. Choi. 2007. An aphelinid species, Aphelinus asychis Walker (Hymenoptera: Aphelinidae) new to Korea. J. Asia-Pacific Entomol. 10: 13-15.

Mann, H. B., and D. R. Whitney. 1947. On a test of whether one or two random variables is stochastically larger than the other. Ann. Math. Statist. 18: 50-60.

Nagasaka, K., N. Takahashi, T. Okabayashi, J. Abe, and S. Ohya. 2005. Development of a practical banker plant technique for aphid control in commercial greenhouse crops in Japan, pp. 30-35. In H. Yasuda (ed.) Proceedings of International Symposium on Biological Control of Aphids and Coccids. Yamagata University, Tsuruoka, Japan.

Parrella, M. P., L. S. Hansen, and J. C. van Lenteren. 1999. Glasshouse environments, pp. 819-839. In T. W. Fisher, T. S. Bellows, L. E. Caltagirone, D. L. Dahlstein, C. B. Huffaker (eds.), Handbook of Biological Control. Academic Press, San Diego, CA.

Perng, J. J., and Y. C. Liu. 2002. Age-specific survival and fecundity and their effects on the intrinsic rate of increase of Aphelinus gossypii (Hym., Aphelinidae), a parasitoid of Aphis gossypii (Hom., Aphididae). J. Appl. Entomol. 126: 484-489.

Pimentel, D, S. A. Levin, and D. A. Olson. 1978. Coevolution and the stability of exploitervictim systems. Am. Nat. 112: 119-125.

Raney, J. M., L. W. Coles, R. D. Eikenbary, R. D. Morrison, and K. J. Starks. 1971. Host preference, longevity, developmental period and sex ratio of Aphelinus asychis with three sorghum-fed species of aphids held at controlled temperatures. Ann. Entomol. Soc. Am. 64: $169-176$. 
Roff, D. A. 1992. The Evolution of Life Histories. Chapman \& Hall, New York.

SAS Publishing. 2008. JMP ver. 8.0 Software, SAS Online, SAS Institute, Cary, NC.

Schlinger, E. I., and J. C. Hall. 1959. A synopsis of the biologies of three imported parasites of the spotted alfalfa aphid. J. Econ. Entomol. 52: 154-157.

Sengonca, C., S. Schirmer, and P. Blaeser. 2008. Life table of the aphid parasitoid Aphelinus asychis (Walker) (Hymenoptera, Aphelinidae) parasitizing different age groups of Aphis gossypii Glover (Homoptera, Aphididae). J. Plant Disease Protec. 115: 112-128.

Takada, H. 2002. Parasitoids (Hymenoptera: Braconidae, Aphidiinae; Aphelinidae) of four principal pest aphids (Homoptera: Aphididae) on greenhouse vegetable crops in Japan. Appl. Entomol. Zool. 37: 237-249.

Tang, Y. Q., and R. K. Yokomi. 1995. Temperature-dependent development of three hymenopterous parasitoids of aphids (Homoptera: Aphididae) attacking citurus. Environ. Entomol. 24: 1736-1740.

Tang, Y. Q., and R. K. Yokomi. 1996. Biology of Aphelinus spiraecolae (Hymenoptera: Aphelinidae) a parasitoid of the spirea aphid (Homoptera: Aphididae). Environ. Entomol. 25: $519-523$.

Tatsumi, E., and H. Takada. 2005. Evaluation of Aphelinus asychis and A. albipodus (Hymenoptera: Aphelinidae) as biological control agents against three pest aphids. Appl. Entomol. Zool. 40: 379-385.

Tatsumi, E., and H. Takada. 2006. Overwintering of the aphid parasitoids Aphelinus asychis and A. albipodus (Hymenoptera: Aphelinidae) under natural conditions in Kyoto, Japan. Appl. Entomol. Zool. 41: 139-144.

Tokumaru, S., and H. Takada. 1996. Numbers of eggs deposited and host feeding in Aphelinus gossypii Timberake (Hymenoptera: Aphelinidae), a parasitoid of Aphis gossypii Glover 
(Homoptera: Aphididae). Jpn. J. Appl. Entomol. Zool 40: 242-244. (in Japanese with English abstract)

Tuda, M. 1996. Temporal/spatial structure and the dynamical property of laboratory hostparasitoid systems. Res. Popul. Ecol. 38: 133-140.

Tuda, M., and M. B. Bonsall. 1999. Evolutionary and population dynamics of host-parasitoid interactions. Res. Popul. Ecol. 41: 81-91.

Tuda, M., and M. Shimada. 1995. Developmental schedules and persistence of experimental host-parasitoid systems at two different temperatures. Oecologia 103: 283-291.

Tuda, M., and M. Shimada. 2005. Complexity, evolution and persistence in host-parasitoid experimental systems, with Callosobruchus beetles as the host. Adv. Ecol. Res. 37: 37-75.

Van Driesche, R. G., S. Lyon, J. P. Sanderson, K. C. Bennett, E. J. S. Tanek, and R. Zhang. 2008. Greenhouse trials of Aphidius colemani (Hymenoptera: Braconidae) banker plants for control of aphids (Hemiptera: Aphididae) in greenhouse spring floral crops. Fla. Entomol. 91: $583-591$.

van Lenteren, J. C., Y. C. Drost, and H. J. W. van Roermund. 1997. Aphelinid parasitoids as sustainable biological control agents in greenhouses. J. Appl. Entomol. 121: 473-485.

van Steenis, M. J., and K. A. M. H. El-Khawass. 1995. Life history of Aphis gossypii on cucumber: influence of temperature, host plant, and parasitism. Entomol. Exp. Appl. 76: 121131.

Vasquez, G. M., D. B. Orr, and J. R.Baker. 2006. Efficacy assessment of Aphidius colemani (Hymenoptera : Braconidae) for suppression of Aphis gossypii (Homoptera : Aphididae) in greenhouse-grown chrysanthemum. J. Econ. Entomol. 99: 1104-1111.

Viggiani, G. 1984. Bionomics of the Aphelinidae. Ann. Rev. Entomol. 29: 257-276

Wagner, T. L., H. -I. Wu, P. J. H. Sharpe, R. M. Schoolfield, and R. N. Coulson. 1984. 
Modeling insect development rates: a literature review and application of a biophysical model. Ann. Entomol. Soc. Am. 77: 208-225.

Wagner, T. L., R. L. Olson, and J. L. Willers. 1991. Modeling arthropod development time. J. Agric. Entomol. 8: 251-270.

Wang, K. -Y., T. -X. Liu, X. -Y. Jiang, and M. -Q. Yi. 2001. Cross-resistance of Aphis gossypii to selected insecticides on cotton and cucumber. Phytoparasitica 29: 393-399.

Wilcoxon, F. 1945. Individual comparisons by ranking methods. Biometrics Bull. 1: 80-83.

Wood, B. W., W. L. Tedders, and C. C. Reilly. 1988. Sooty mold fungus on pecan foliage suppresses light penetration and net photosynthesis. Hortscience 23: 851-853.

Wu, Z., and G. E. Heimpel. 2007. Dynamic egg maturation strategies in an aphid parasitoid. Physiol. Entomol. 32: 143-149.

Zamani, A. A., A. Talebi, Y. Fathipour, and V. Baniameri. 2007. Effect of temperature on life history of Aphidius colemani and Aphidius matricariae (Hymenoptera: Braconidae), two parasitoids of Aphis gossypii and Myzus persicae (Homoptera: Aphididae). Environ. Entomol. 36: $263-271$.

Zhu, Y. C., and Q. Q. Fang. 2009. The phylogenetic relationships of introduced Aphelinus (Hymenoptera: Aphelinidae), biological control agents of the Russian wheat aphid (Homoptera: Aphididae). Insect Sci. 16: 277-285. 
Table 1. Development times (d) of the females and males of A. asychis on A. gossypii at $25^{\circ} \mathrm{C}$.

\begin{tabular}{ccrrr}
\hline \multirow{2}{*}{ Stage } & \multicolumn{2}{c}{ Female } & \multicolumn{2}{c}{ Male } \\
\cline { 2 - 5 } & Mean \pm SE & Range & Mean \pm SE & Range \\
\hline Egg to mummification & $6.0 \pm 0.3$ & $6.0-7.0$ & $5.9 \pm 0.3$ & $5.5-6.5$ \\
Mummification to adult & $7.9 \pm 0.6$ & $7.0-8.5$ & $7.4 \pm 0.6$ & $6.0-9.0$ \\
emergence & & & & \\
Egg to adult emergence & $13.9 \pm 0.3$ & $12.5-13.5$ & $13.2 \pm 0.8$ & $12.0-15.0$ \\
$n$ & 136 & & & 126 \\
\end{tabular}


Table 2. Longevity (d) and fecundity (number of mummies formed) of A. asychis on A. gossypii at $25^{\circ} \mathrm{C}(n=12)$

\begin{tabular}{crr}
\hline & \multicolumn{1}{c}{ Mean \pm SE } & \multicolumn{1}{c}{ Range } \\
\hline Longevity in females & $21.3 \pm 0.9$ & $14-24$ \\
in males & $8.2 \pm 0.5$ & $6-11$ \\
Fecundity per day & $14.9 \pm 0.4$ & $13-17$ \\
Fecundity until parasitoid died & $342.6 \pm 13.2$ & $237-404$ \\
\hline
\end{tabular}


Table 3. Development times from egg to mummy, mummy to adult emergence and egg to adult emergence of $A$. asychis at eight constant temperatures (days, means $\pm \mathrm{SE}$ ). Means within the same period were significantly different among different temperatures for all three periods (see text). $n$ refers to the number of emerging adults

\begin{tabular}{|c|c|c|c|c|c|c|}
\hline \multirow[b]{2}{*}{$\begin{array}{l}\text { Temp. } \\
\left({ }^{\circ} \mathrm{C}\right)\end{array}$} & \multirow[b]{2}{*}{$n$} & \multicolumn{3}{|l|}{ Period } & \multirow[b]{2}{*}{$\begin{array}{l}\text { Prop. } \\
\text { of } \\
\text { females }\end{array}$} & \multirow[b]{2}{*}{$\begin{array}{l}\text { Pupal } \\
\text { mortality } \\
(\%)\end{array}$} \\
\hline & & $\begin{array}{l}\text { Egg to } \\
\text { mummy }\end{array}$ & $\begin{array}{l}\text { Mummy to } \\
\text { adult } \\
\text { emergence }\end{array}$ & $\begin{array}{l}\text { Egg to } \\
\text { adult } \\
\text { emergence }\end{array}$ & & \\
\hline 15.0 & 97 & $13.4 \pm 0.05$ & $14.3 \pm 0.05$ & $27.8 \pm 0.09$ & 0.474 & 13.4 \\
\hline 17.5 & 119 & $11.5 \pm 0.05$ & $10.3 \pm 0.05$ & $21.7 \pm 0.05$ & 0.471 & 16.8 \\
\hline 20.0 & 173 & $9.1 \pm 0.04$ & $9.6 \pm 0.04$ & $18.7 \pm 0.07$ & 0.509 & 9.9 \\
\hline 22.5 & 255 & $7.2 \pm 0.03$ & $8.0 \pm 0.03$ & $15.2 \pm 0.04$ & 0.584 & 16.4 \\
\hline 25.0 & 262 & $6.0 \pm 0.03$ & $7.6 \pm 0.03$ & $13.5 \pm 0.05$ & 0.519 & 18.4 \\
\hline 27.5 & 97 & $5.6 \pm 0.05$ & $6.5 \pm 0.05$ & $12.1 \pm 0.09$ & 0.526 & 15.6 \\
\hline 30.0 & 232 & $5.2 \pm 0.03$ & $5.1 \pm 0.03$ & $10.3 \pm 0.06$ & 0.517 & 11.1 \\
\hline 32.5 & 138 & $4.9 \pm 0.04$ & $4.8 \pm 0.04$ & $9.8 \pm 0.08$ & 0.652 & 18.1 \\
\hline
\end{tabular}


Table 4. Linear regression equations of developmental rate in relation to temperatures, estimated lower developmental threshold $\left(T_{0}\right)$ and thermal constant $(D D)$ for the immature stages of $A$. asychis. Data on development of egg to mummy, mummy to adult emergence and egg to adult emergence were obtained at six constant temperatures between 17.5 and $30^{\circ} \mathrm{C}$

\begin{tabular}{|c|c|c|c|c|c|c|c|c|}
\hline \multirow[b]{2}{*}{ Period } & \multirow{2}{*}{$\begin{array}{l}\text { Slope, } b \\
( \pm \mathrm{SE})\end{array}$} & \multirow{2}{*}{$\begin{array}{l}\text { Intercept, } \\
a \\
( \pm \mathrm{SE})\end{array}$} & \multicolumn{3}{|c|}{ ANOVA parameters } & \multirow[b]{2}{*}{$R^{2}$} & \multirow{2}{*}{$\begin{array}{l}T_{0} \\
( \pm \quad \mathrm{SE}) \\
\left({ }^{\circ} \mathrm{C}\right)\end{array}$} & \multirow{2}{*}{$\begin{array}{l}D D \\
( \pm \mathrm{SE}) \\
\left({ }^{\circ} \mathrm{C} \mathrm{d}\right)\end{array}$} \\
\hline & & & $F$ & $d f$ & $P$ & & & \\
\hline $\begin{array}{l}\text { Egg }- \\
\text { mummy }\end{array}$ & $\begin{array}{l}0.00867 \\
( \pm 0.00012)\end{array}$ & $\begin{array}{l}-0.0582 \\
( \pm 0.003)\end{array}$ & 5433.6 & 1137 & $<0.001$ & 0.827 & $\begin{array}{l}6.7 \\
( \pm 0.25)\end{array}$ & $\begin{array}{l}115 \\
( \pm 1.6)\end{array}$ \\
\hline $\begin{array}{l}\text { Mummy - } \\
\text { adult } \\
\text { emergence }\end{array}$ & $\begin{array}{l}0.00795 \\
( \pm 0.000098)\end{array}$ & $\begin{array}{l}-0.0543 \\
( \pm 0.002)\end{array}$ & 6569.9 & 1137 & $<0.001$ & 0.853 & $\begin{array}{l}6.8 \\
( \pm 0.22)\end{array}$ & $\begin{array}{l}126 \\
( \pm 1.6)\end{array}$ \\
\hline $\begin{array}{l}\text { Egg - adult } \\
\text { emergence }\end{array}$ & $\begin{array}{l}0.00412 \\
( \pm 0.000038)\end{array}$ & $\begin{array}{l}-0.0278 \\
( \pm 0.0009)\end{array}$ & 11595.6 & 1137 & $<0.001$ & 0.911 & $\begin{array}{l}6.7 \\
( \pm 0.16)\end{array}$ & $\begin{array}{l}243 \\
( \pm 2.2)\end{array}$ \\
\hline
\end{tabular}


Appendix 1. Comparison of longevity of adult female, numbers of eggs deposited and aphids killed by non-reproductive activity among seven Aphelinus species

\begin{tabular}{|c|c|c|c|c|c|c|c|c|c|c|c|c|c|}
\hline \multirow{2}{*}{$\begin{array}{l}\text { Aphelinus } \\
\text { species }\end{array}$} & \multirow{2}{*}{$\begin{array}{l}\text { Temp } \\
\left({ }^{\circ} \mathrm{C}\right)\end{array}$} & \multirow{2}{*}{ Host aphid } & \multirow{2}{*}{ Reared host } & \multirow{2}{*}{$\begin{array}{l}\text { No. and } \\
\text { age/stage of } \\
\text { aphids } \\
\text { provided }\end{array}$} & \multirow{2}{*}{$\begin{array}{l}\text { Longe } \\
\text { vity of } \\
\text { female } \\
\text { (d) }\end{array}$} & \multirow{2}{*}{$\begin{array}{l}\text { Number, } \\
\text { time and } \\
\text { remating } \\
\text { chance } \\
\text { with males }\end{array}$} & \multirow{2}{*}{$\begin{array}{l}\text { Male } \\
\text { longe } \\
\text { vity } \\
\text { (d) }\end{array}$} & \multicolumn{2}{|c|}{$\begin{array}{l}\text { Mean number of } \\
\text { eggs deposited }\end{array}$} & \multicolumn{2}{|c|}{$\begin{array}{l}\text { Mean number of } \\
\text { aphids killed }\end{array}$} & \multirow{2}{*}{$\begin{array}{l}\text { Total } \\
\text { no. } \\
\text { attacke } \\
\text { d } \\
\text { aphids }\end{array}$} & \multirow{2}{*}{ References } \\
\hline & & & & & & & & daily & total & daily & total & & \\
\hline asychis & 26.7 & $\begin{array}{l}\text { Schizaphis } \\
\text { graminum }\end{array}$ & S. graminum & $\begin{array}{l}20 \text { (mixed } \\
\text { stage) }\end{array}$ & 23.4 & $1,-$, yes & - & ca. $10^{*}$ & $233^{*}$ & ca. 1.5 & 30.4 & 263.4 & $\begin{array}{l}\text { Cate et al. } \\
(1973)\end{array}$ \\
\hline asychis & 25 & $\begin{array}{l}\text { Acyrthosiphon } \\
\text { pisum }\end{array}$ & A. pisum & $40\left(2^{\text {nd }}\right.$ instar $)$ & - & $\begin{array}{l}\text { unknown, } \\
\text { no }\end{array}$ & - & ca. 8 & - & ca. 1 & - & - & $\begin{array}{l}\text { Bai and } \\
\text { Mackauer } \\
(1990)\end{array}$ \\
\hline \multirow[t]{3}{*}{ asychis } & 25 & $\begin{array}{l}\text { Aphis } \\
\text { gossypii }\end{array}$ & A. gossypii & $\begin{array}{l}20-50(1-2 d- \\
\text { old })\end{array}$ & 32.8 & $\begin{array}{l}\text { unknown, } \\
\text { no }\end{array}$ & $\begin{array}{l}15^{* *} \\
*\end{array}$ & $7.3^{*}$ & $232.3^{*}$ & 7.5 & 161.2 & 393.5 & $\begin{array}{l}\text { Sengonca et al. } \\
\text { (2008) }\end{array}$ \\
\hline & & & & $\begin{array}{l}20-50(4-5 d- \\
\text { old) }\end{array}$ & 25.2 & & & $1.7^{*}$ & $21.1^{*}$ & 4.0 & 87.9 & 109 & \\
\hline & & & & 20-50 (adult) & 24.2 & & & $0.7^{*}$ & $44.7^{*}$ & 3.8 & 42.7 & 87.4 & \\
\hline asychis & 25 & A. gossypii & S. graminum & 50 ( $2^{\text {nd }}$ instar $)$ & 21.3 & $2,4 \mathrm{~h}$, yes & 8.2 & $14.9 *$ & $342.6^{*}$ & $3.3 * *$ & $73.9 * *$ & 416.5 & Present study \\
\hline semiflavus & 26.7 & $\begin{array}{l}\text { Therioaphis } \\
\text { maculata }\end{array}$ & T. maculata & $\begin{array}{l}75-100 \text { (mixed } \\
\text { stage) }\end{array}$ & ca. 26 & unknown & - & $\begin{array}{l}\text { ca. } \\
14.8\end{array}$ & 385 & - & - & - & $\begin{array}{l}\text { Force and } \\
\text { Messenger } \\
(1964 a)\end{array}$ \\
\hline \multirow[t]{2}{*}{$\begin{array}{l}\text { abdominali } \\
S\end{array}$} & 20 & $\begin{array}{l}\text { Sitobion } \\
\text { avenae }\end{array}$ & S. avenae & $\begin{array}{l}150 \text { aphids / } 5 \\
\text { d (mixed stage, } \\
\text { large cage) }\end{array}$ & 51 & unmated & - & ca. 11 & ca.574 & - & - & - & $\begin{array}{l}\text { Höller and } \\
\text { Haardt (1993) }\end{array}$ \\
\hline & & & & & 52 & $1,-$, yes & 5 & $\begin{array}{l}\text { ca. } \\
14.4\end{array}$ & ca. 751 & - & - & - & \\
\hline albipodus & 26.7 & $\begin{array}{l}\text { Diuraphis } \\
\text { noxia }\end{array}$ & D. noxia & $\begin{array}{l}100\left(\text { mixed } 3^{\text {rd }}\right. \\
\& 4^{\text {th }} \text { instar and } \\
\text { adult) }\end{array}$ & 16.4 & $1,-$, yes & 10 & $17.9^{*}$ & $294.7 *$ & - & - & - & $\begin{array}{l}\text { Bernal et al. } \\
\text { (1997) }\end{array}$ \\
\hline albipodus & 25 & $\begin{array}{l}\text { Aphis glycine } \\
\text { S }\end{array}$ & A. glycines & $\begin{array}{l}501^{\text {st }} \text { instar } \\
502^{\text {nd }} \text { instar } \\
503^{\text {rd }} \text { instar } \\
504^{\text {th }} \text { instar } \\
50 \text { adult alate }\end{array}$ & - & $1,3 \mathrm{~h}$, no & - & $\begin{array}{l}\text { ca. } 22 \\
\text { ca. } 13 \\
\text { ca. } 12 \\
\text { ca. } 4 \\
\text { ca. } 1\end{array}$ & - & $\begin{array}{l}\text { ca. } 5 \\
\text { ca. } 8 \\
\text { ca. } 4 \\
\text { ca. } 2 \\
\text { ca. } 2\end{array}$ & - & - & $\begin{array}{l}\text { Wu and } \\
\text { Heimpel (2007) }\end{array}$ \\
\hline
\end{tabular}




\begin{tabular}{|c|c|c|c|c|c|c|c|c|c|c|c|c|c|}
\hline flavus & - & $\begin{array}{l}\text { Drepanosiphu } \\
\text { m platanoidis }\end{array}$ & D. platanoidis & $6\left(1^{\text {st }}\right.$ instar $)$ & 27 & unmated & - & 1.8 & 48 & 1.2 & 28 & 76 & $\begin{array}{l}\text { Hamilton } \\
\text { (1973) }\end{array}$ \\
\hline gossypii & 18 & A. gossypii & A. gossypii & 30 ( $3^{\text {rd }}$ instar $)$ & 8 & $\begin{array}{l}2 \text { or } 3,- \\
\text { no }\end{array}$ & - & 8.0 & 57 & 1.5 & 10.7 & 67.7 & $\begin{array}{l}\text { Tokumaru and } \\
\text { Takada (1996) }\end{array}$ \\
\hline gossypii & 25 & A. gossypii & A. gossypii & $\begin{array}{l}50(24-48 \mathrm{~h} \\
\text { old })\end{array}$ & 26.3 & $1,6 h$, yes & 1 & 22.8 & $599 *$ & ca. 3-4 & 87.9 & 676.9 & $\begin{array}{l}\text { Perng and Liu } \\
(2002)\end{array}$ \\
\hline spiraecolae & 24 & $\begin{array}{l}\text { Aphis spir } \\
\text { aecola }\end{array}$ & A. spiraecola & $\begin{array}{l}50\left(2^{\text {nd }} \& 3^{\text {rd }}\right. \\
\text { instar })\end{array}$ & 17.8 & $2,4 \mathrm{~h}$, no & - & 6.7 & 138.2 & 1.9 & 27.1 & 165.3 & $\begin{array}{l}\text { Tang and } \\
\text { Yokomi (1996) }\end{array}$ \\
\hline
\end{tabular}

* Number of mummies formed.

** Byeon et al. (2009)

*** Estimated without female 
Appendix 2. Comparison of lower development threshold temperatures $\left(T_{0}\right)$ and thermal constants $(D D)$ of $A$. asychis and aphidiine parasitoids of different geographic origins. Numbers in bold are the parameters for parasitoids when using A. gossypii

\begin{tabular}{|c|c|c|c|c|c|}
\hline $\begin{array}{l}\text { Parasitic } \\
\text { wasps }\end{array}$ & $\begin{array}{l}\text { Country of } \\
\text { origin }\end{array}$ & Host aphids & $\begin{array}{l}T_{0} \\
\left( \pm \mathrm{SE},{ }^{\circ} \mathrm{C}\right)\end{array}$ & $\begin{array}{l}D D \\
( \pm \mathrm{SE})\end{array}$ & References \\
\hline Aphelinus & Middle East & Therioaphis & $10.6 \pm 0.8$ & $190 \pm 1$ & Re-estimated from \\
\hline $\begin{array}{l}\text { asychis (as } \\
\text { A. } \\
\text { semiflavus, } \\
\text { female) }\end{array}$ & $\begin{array}{l}\text { and Southern } \\
\text { Europe }\end{array}$ & maculata & 2 & 1.4 & $\begin{array}{l}\text { Force and } \\
\text { Messenger (1964b) }\end{array}$ \\
\hline \multirow[t]{5}{*}{ A. asychis } & \multirow[t]{5}{*}{ Iran } & Sipha flava & $6.2 \pm 1.53$ & $\begin{array}{l}301 \pm 2 \\
0.6\end{array}$ & \multirow[t]{5}{*}{$\begin{array}{l}\text { Re-estimated from } \\
\text { Raney et al. (1971) }\end{array}$} \\
\hline & & Schizaphis & $12.7 \pm 0.5$ & $177 \pm 6$ & \\
\hline & & graminum & 1 & .4 & \\
\hline & & Rhopalosiphu & $11.6 \pm 2.9$ & $199 \pm 3$ & \\
\hline & & $m$ maidis & 3 & 4.2 & \\
\hline \multirow[t]{2}{*}{ A. asychis } & Chillan, & Diuraphis & $7.5 \pm 0.81$ & $238 \pm 1$ & \multirow{3}{*}{$\begin{array}{l}\text { Re-estimated from } \\
\text { Bernal and Gonzalez } \\
\text { (1993) }\end{array}$} \\
\hline & Chile & noxia & & 5.5 & \\
\hline A. asychis & $\begin{array}{l}\text { Antibes, } \\
\text { France }\end{array}$ & D. noxia & $8.0 \pm 1.23$ & $\begin{array}{l}233 \pm 2 \\
3.5\end{array}$ & \\
\hline A. asychis & $\begin{array}{l}\text { Pingluo, } \\
\text { China }\end{array}$ & D. noxia & $9.2 \pm 0.65$ & $\begin{array}{l}215 \pm 1 \\
1.8\end{array}$ & $\begin{array}{l}\text { Re-estimated from } \\
\text { Lee and Elliott }\end{array}$ \\
\hline A. asychis & $\begin{array}{l}\text { Sette, } \\
\text { Morocco }\end{array}$ & D. noxia & $\begin{array}{r}10.5 \pm 0.6 \\
4\end{array}$ & $\begin{array}{l}181 \pm 1 \\
0.9\end{array}$ & (1998) \\
\hline A. asychis & $\begin{array}{l}\text { Hoengseong, } \\
\text { Korea }\end{array}$ & Aphis gossypii & $6.7 \pm 0.16$ & $\begin{array}{l}243 \pm 2 \\
.2\end{array}$ & Present study \\
\hline $\begin{array}{l}\text { Aphidius } \\
\text { matricariae }\end{array}$ & Northern Iraq & D. noxia & $2.4 \pm 0.66$ & $\begin{array}{l}285 \pm 1 \\
5.4\end{array}$ & \multirow{2}{*}{$\begin{array}{l}\text { Re-estimated from } \\
\text { Bernal and Gonzalez } \\
\text { (1993) }\end{array}$} \\
\hline $\begin{array}{l}\text { Diaeretiella } \\
\text { rapae }\end{array}$ & $\begin{array}{l}\text { Northwestern } \\
\text { Pakistan }\end{array}$ & D. noxia & $4.6 \pm 0.68$ & $\begin{array}{l}242 \pm 1 \\
1.0\end{array}$ & \\
\hline \multirow[t]{2}{*}{ colemani } & Tehran, Iran & A. gossypii & $6.3 \pm 0.19$ & $\begin{array}{l}187 \pm 2 \\
.8\end{array}$ & \multirow[t]{4}{*}{ Zamani et al. (2007) } \\
\hline & & $\begin{array}{l}\text { Myzus } \\
\text { persicae }\end{array}$ & $6.7 \pm 0.59$ & $\begin{array}{l}181 \pm 8 \\
.8\end{array}$ & \\
\hline \multirow[t]{2}{*}{$\begin{array}{l}\text { Aphidius } \\
\text { matricariae }\end{array}$} & Tehran, Iran & A. gossypii & $6.2 \pm 1.28$ & $\begin{array}{l}212 \pm 2 \\
6.4\end{array}$ & \\
\hline & & M. persicae & $6.4 \pm 1.00$ & $\begin{array}{l}213 \pm 1 \\
7.1\end{array}$ & \\
\hline
\end{tabular}


Figure legend

Fig. 1. Daily fecundity and percentage survival of $A$. asychis adults when provided with 50 A. gossypii (second instar) per day at $25^{\circ} \mathrm{C}$.

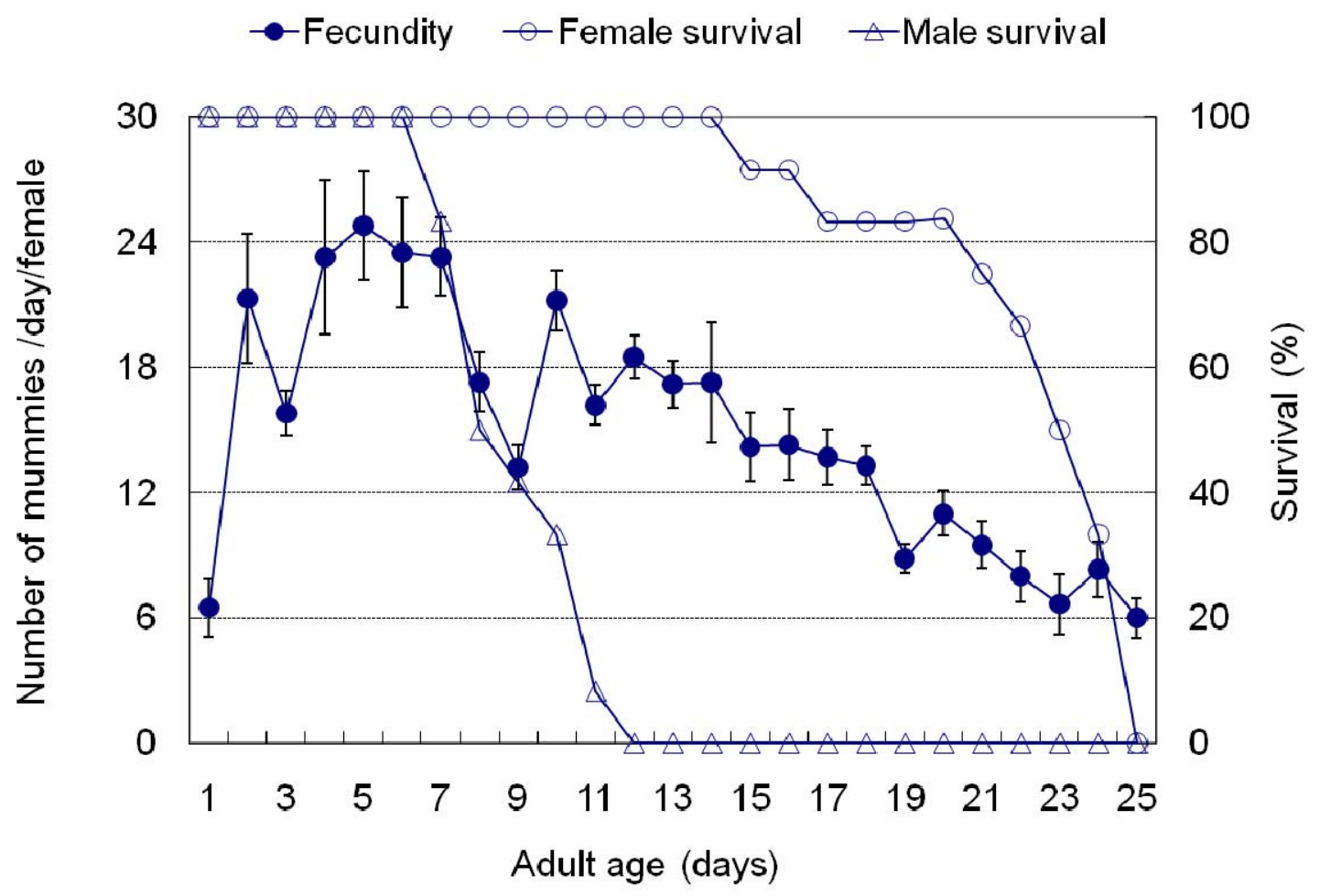

